\title{
Tradisionele geloof
}

W A Dreyer \& F E Mjwabe

Roodepoort

\begin{abstract}
Traditional belief

Traditional belief is still very strong among black South Africans. Many Christians not only believe in Christ, but also in the spirits of the forefathers. The question arises as to how the relationship between traditional belief and cristian faith must be seen. It also poses problems to the church in South Africa, which is mainly orientated to the theology of Western Europe. Proclaiming the gospel in a traditional situation will only be effective if traditional beliefs are taken into consideration. This article uses oral tradition as a source of information.
\end{abstract}

\section{INLEIDING}

Hierdie artikel is geskryf nadat daar gesprek gevoer is met verskillende persone in die swart gemeenskap, onder andere praktiserende sangomas. Die rede hiervoor is dat tradisionele geloof primêr mondelings, van geslag tot geslag oorgedra word en nie skriftelik nie (Verkuyl 1978:278). Talle van die Westerse teoloë wat in die verlede oor tradisionele geloof geskryf het, was besonder eensydig in hulle benadering. Daarom is daar gepoog om iets van die mondelingse tradisie weer te gee. Daar sal onder andere gepoog word om 'n omskrywing te gee van die modimo, badimo, sangoma en die baloyi. Onmiddelik moet egter gesê word dat groot variasies in die tradisionele geloof bestaan. Ten spyte van die variasies is genoemde begrippe egter redelik algemeen. Daar bestaan ook verskillende benaminge in die verskillende tale vir bogenoemde terme. In hierdie artikel word volstaan met die Sotho-benaming.

\section{MODIMO}

Daar bestaan in Afrika verskillende name vir 'god'. In Sotho heet hy modimo. Hy is die opperwese. Hierdie opperwese is fundamenteel aan alle Afrika-godsdienste (Oosthuizen 1978:265). In die tradisionele geloof is die modimo die een wat alles geskep het, en alles steeds onderhou. Hy word gesien as 'n koning wat regeer oor die hele wêreld. Hierdie opvatting lei tot 'n teokratiese wêreldbeeld. Dit is ook deur die bemiddeling van die modimo dat die mens bestaan en hy sorg dat die mens voorspoed of teëspoed beleef. Hy besluit wie die ewige lewe ontvang, en wie nie. Die modimo is 
die een wat aanbid word en hy luister ook na die probleme van die persoon wat tot hom bid. Hy kan dan ook 'n verandering in die omstandighede van so 'n persoon teweegbring.

\section{BADIMO}

Die badimo is die voorvaders in die tradisionele geloof. Hierdie voorvaders is die mense wat die tradisies aan hulle kinders geleer het voor hulle te sterwe gekom het. Die badimo is die afgestorwenes. In die tradisionele geloof word hulle nie as 'dood' beskou nie, maar as slapende. Die modimo het hulle geroep en hulle is dus by die modimo in die hemel. Daarom is die badimo nie dooies nie, maar hulle is lewend.

Die badimo, so word daar geglo, is ook altyd by hulle familie. Hulle staan in die nag op en kuier by hulle familie. Hulle gaan altyd terug na hulle familie en kinders om te kyk hoe hulle lewe. Hulle gaan in die gees na die familie en word dus voorgestel as geeste. Wanneer hulle so in die nag by hulle familie kom kuier, praat hulle met die mense in die huis, deur drome. As iemand dus droom van sy/haar pa of 'n gestorwe familielid, dan word dit beskou as 'n besoek van die badimo en word dit ervaar as 'n gesprek wat met die badimo plaasgevind het. Enigiets wat deur die badimo in die droom aan die persoon gesê is, word beskou as 'n opdrag wat uitgevoer moet word. Die badimo kan byvoorbeeld aan die een wat droom, sê dat hulle honger is en dat daar 'n koei, 'n wit bok of 'n wit hoender vir hulle geslag moet word. Indien die versoek verontagsaam sou word, sal die kinders en die familie gestraf word. Straf deur die badimo kan die vorm van siekte, verlies van besittings of selfs die dood aanneem. Die badimo beskik verder oor die mag om geluk of ongeluk oor hulle familie te bring. Dit laat die vraag ontstaan of hulle as gode beskou moet word? Die algemene opvatting is egter dat hulle nie gode in dieselfde sin as die modimo is nie.

Hulle is en bly mense, maar omdat hulle oorgegaan het na 'n geestelike bestaan en by die modimo is, het hulle besondere kragte. Etimologies is modimo en badimo verwant: Eersgenoemde is die enkelvoud en laasgenoemde die meervoudsvorm van modimo. Dit beteken egter nie dat mens van 'god' en 'gode' kan praat nie. Semanties gesproke is dit 'god' en 'mense van god', dit wil sê mense wat by god leef. Hulle het dus mag, maar hulle is nie almagtig nie. Die mag van die badimo is kleiner as dié van die modimo, en dit is die verskil tussen die modimo en die badimo. Die tradisionele geloof se opvatting behels verder dat die badimo alsiende is en alles weet wat in die wêreld aangaan. Mense wat probleme het, sal beide die modimo en badimo aanroep met die woorde ngwama enwa o furalletswe ke modimo re badimo. 
Hieruit word dit duidelik waarom die begrafnis in die tradisionele geloof so belangrik geag word, en inderdaad as die belangrikste godsdienstige handeling beskou word. Nie net die lewendes is by die begrafnis teenwoordig nie, maar ook die badimo. Die lewende en gestorwe familie is dus volgens die tradisionele geloof by die begrafnis teenwoordig. Die begrafnis is vir die lewende familie 'n geleentheid waar hulle met die gestorwe familie kan kommunikeer. Omdat die badimo in die nag besoek by die lewendes aflê, bestaan die begrafnis onder andere uit die nagwaak. Tydens die nagwaak word daar met die badimo gepraat en word probleme aan hulle oorgedra en hulle hulp ingeroep. So word die begrafnis die geleentheid waar verlede, hede en toekoms ontmoet. So word die grense van tyd uitgewis.

Die diens aan die badimo vorm 'n wesenlike deel van die kultuur van die swart gemeenskap, hoewel die mense wat verwesters het, die tradisies nie meer so sterk handhaaf nie. Dit is egter nie net tradisionele swart gemeenskappe wat die voorvaderdiens in stand hou nie, maar ook in die stede en selfs in Christelike gemeentes word dit beoefen.

Voordat iemand oorgaan tot die voorvaderdiens (ritueel), moet hy eers van die badimo droom. 'n Gestorwe vader of oupa verskyn in die droom en sê aan die persoon wat droom, dat hy honger is. Dit is die teken dat die badimo gedien moet word en die hele familie word by die diens betrek. Daar word dan kos en bier vir die badimo uitgesit. Die een wat die droom gehad het, moet die bok of skaap slag en ook bier brou wat saam met die kos uitgesit word. Terwyl hy dit doen, moet almal wat naby bly (veral die familie), teenwoordig wees. Nadat die kos en bier voorberei is, word die porsie van die badimo na 'n kamer geneem en daar neergesit. Voordat die vertrek verlaat word, word daar eers gebid en met die modimo asook met die badimo gepraat. As alles in orde is, kom die badimo deur die nag en hulle eet van die kos en drink van die bier. Die badimo wat besoek aflê by die familie, is verteenwoordigend van alle ouderdomme. Net soos in die geval van die lewendes, is dit net die ou manne wat die bier drink. Die jonges eet net van die kos. Die bier sal in die kamer gelaat word totdat alles op is. Die oorblyfsels van die dier wat geslag is, word verbrand, sodat 'n vyandige persoon dit nie in die hande kan kry en die familie toor nie.

\section{SANGOMA}

Daar kan twee soorte sangomas onderskei word: Die een groep sangomas werk met tradisionele hulpmiddels soos die dolosse, terwyl die ander groep met die Bybel werk. Die Bybel funksioneer baie soos die dolos by die eerste groep. Voordat iemand 'n sangoma kan word, moet hy of sy eers droom waarin die voorvaders aan die persoon bekend mak dat hy geroep is as sangoma. In die droom sien die persoon dolosse, muti en die hare van die sangoma (wat op 'n besondere wyse versorg word en die sim- 
bool van die sangoma is). Verder sien die persoon in die droom waarheen hy/sy moet gaan, vir sy/haar opleiding. 'n Praktiserende sangoma het haar roeping soos volg beskryf:

Sy het in haar droom gesien dat sy na die rivier moes gaan. Toe sy by die rivier aangekom het, het die water oopgegaan, en sy het in die rivier ingestap. Sy was in die middel van die rivier, maar waar sy gestaan het was dit droog. Sy het drie ou manne in die rivier gekry. Hulle het met haar gepraat. Voor hulle op die grond was daar 'n groot potdeksel waarin muti en dolosse gelê het. Iemand verskyn toe voor haar en sê vir haar daar sal 'n ding na haar kom, 'n baie lelike ding. Sy moet haar oë heeltemaal toehou en glad nie kyk na die ding nie, anders sal sy nie weer uit die rivier kom nie. Sy het haar oë dig toegemaak, en voel toe dat iets haar begin lek. Die lelike ding sê toe vir haar dat sy moet loop, en die dolos en muti in die potdeksel moet saamvat. Sy het dit gedoen en die rivier uitgestap.

(Mededeling deur praktiserende sangoma).

Die rol en die funksie van sangomas in die gemeenskap bestaan daaruit dat hulle mense met probleme help deur raad te gee en om met die badimo te kommunikeer. So vervul hulle 'n soort 'pastorale' funksie. Die sangoma het gevolglik 'n hoë status in die gemeenskap, en word deur almal in die gemeenskap gerespekteer. Hulle word gereeld na feeste uitgenooi om daar op te tree. Dit word gedoen deur rituele danse waar die mense dan saam met die sangoma dans. Die sangoma verteenwoordig die goeie in gemeenskap en moet dikwels die bose in die gemeenskap bestry. Só word hulle hulp byvoorbeeld ingeroep om die mag van die bose te verbreek, om iemand wat getoor is te help en om towenaars uit te wys. Somtyds word 'n towenaar uitgewys en dan word hy verbrand. Die sangoma funksioneer dus as simbool van die goeie in die gemeenskap.

Die insig en krag van die sangomas ontvang hulle van die badimo. Dit is ook die badimo wat die dolosse beheer. Deur die dolosse dra die badimo boodskappe oor aan die lewendes. Die sangoma is dus ' $n$ medium tussen die gestorwe en die lewende familie wat positiewe boodskappe oor dra. Die handelinge van die sangoma is primêr religieus: Voordat die badimo geraadpleeg word, word daar eers gebid. Eerstens word die modimo aangeroep, en daarna die badimo. Daar word in die gebed gevra dat die sangoma, dolos en muti krag sal kry, sodat dit kan werk. 
Daar is, soos genoem, ook sangomas wat die Bybel gebruik in die plek van dolosse. Wanneer 'n persoon na die sangoma kom vir raad en advies, gee hy/sy aan hom 'n Bybel wat op enige plek oopgemaak moet word. Daarna word die Bybel aan die sangoma teruggegee, wat dan aan die hand van die betrokke Skrifgedeelte die persoon se probleme verklaar en aan hom/haar leiding gee. Indien dit siekte is waarmee die persoon worstel, gee die sangoma aan hom/haar muti. Muti is tradisionele medisyne wat in die veld versamel word. Die sangoma gee só geestelike sowel as mediese leiding aan mense.

\section{BALOYI}

Die baloyi is die towenaars in die gemeenskappe waar tradisionele geloof beoefen word. Hulle verteenwoordig die bose en wend die dolosse en die muti op 'n negatiewe wyse aan. Hulle gebruik dit om mense toor, sodat hulle siek word en selfs kan sterf. Hulle kan ook die tokolosi na iemand stuur om die persoon skade aan te doen. Die tokolosi is 'n klein mannetjie (dwerg) wat mense kwaad aandoen. Die baloyi het ook beheer oor die weerlig en hulle wend dit aan om mense dood te maak.

Die baloyi verteenwoordig die bose in die gemeenskap en hulle word gevrees en gehaat. Tog word hulle ook geraadpleeg, byvoorbeeld as daar 'n liefdesstryd tussen twee mense is. Die baloyi word beskou as medewerkers van die duiwel. Die baloyi is uitgeworpenes en word glad nie in die gemeenskap aanvaar nie. Die baloyi het ook al op die gebied van die politiek negatiewe gevolge gehad, waar politieke teenstanders as baloyi uitgewys is en dan as gevolg van sulke bewerings verbrand is - dikwels met die halssnoermetode.

\section{DIE VERHOUDING TUSSEN DIE CHRISTELIKE EVANGELIE EN DIE TRADISIONELE GELOOF}

Die werklikheid waarmee die kerk rekening moet hou, is dat talle lidmate steeds aan die tradisionele geloof vashou. Daar is selfs sangomas wat as leiers in Christelike gemeentes optree. Hulle assosieer die modimo met God die Vader. Jesus Christus en die Heilige Gees skep in hierdie opvatting ook geen probleem rie, aangesien daar aan 'n veelheid van geestelike wesens geglo word. Verder word die leer oor die opstanding uit die dood maklik aanvaar, omdat dit versoenbaar is met 'n wesenlike deel van tradisionele geloof. Op hierdie wyse word die weg vir die verkondiging van die evangelie van Jesus Christus gebaan. Verder neem die predikant en die kerk stelselmatig die rol en die funksie van die sangoma in die gemeenskap oor. In die denke van talle tradisionele gelowiges is daar dikwels geen botsing tussen die Christelike evangelie en hulle tradisionele geloof nie. Daarom bly hulle maklik tegelyk tradisionele gelowiges en ook Christene. 
Dit is opmerklik dat die sendingkerke wat by die tradisionele geloof aansluiting gevind het, vinniger gegroei het as die kerke waar daar suiwer Christelik en gereformeerd gepreek is. Daar is twee gevare aan die hele situasie verbonde: aan die een kant is daar die gevaar van sinkretisme (vgl Van der Westhuizen 1990:54 e v) en die vernietiging van basiese Christelike waarhede, en aan die ander kant is daar die gevaar dat die evangelieverkondiging kultuuroordrag kan word. Die sending het in die verlede dikwels gefaal omdat dit meer kultuuroordrag as evangelieverkondiging geword het (vgl Bosch 1979:134).

Daar bestaan nie 'vleeslose', geskiedenislose, kultuurlose en godsdienslose mense in die wêreld nie (Bavinck 1954:87). Die mense wat die evangelie hoor, se lewens- en wêreldbeskouing word inderdaad bepaal deur dinge soos hulle kultuur, godsdiens, taal, ekonomie en politiek. Daar moet deeglik met al hierdie dinge rekening gehou word in die verkondiging van die evangelie. Die evangelie moet in die konkrete situasie van die mense verkondig word, en daarom moet daar ook met die tradisionele geloof rekening gehou word. Die evangelieverkondiging in die tradisionele gemeenskap moet daarom met besondere insig benader word.

Kennis van die tradisionele gelowe is noodsaaklik, want die wêreld van mense wat in primitiewe omstandighede leef, is nie dieselfde as die wêreld van moderne verwesterse mense nie. Eersgenoemde se denkkategorië, en só ook hulle beskouing van godsdiens, verskil radikaal van mense wat in die klassieke godsdienstige tradisie opgegroei het (Neill 1977:126). Daarom is gesprek oor die tradisionele geloof en die Christelike evangelie nodig. So ' $n$ gesprek lei tot kennis van die ander en daardie kennis is van waarde waar die evangelie verkondig word aan mense wat die tradisionele geloof beoefen. Hierdie gesprek toon verder respek vir die ander en hulle tradisies.

Die vraag wat Verkuyl (1978:279) aan die orde gestel het, is: 'If ancestor worship is the vessel from which Africans has been dirinking so long, should Christians smash it to pieces and offer another in its place or merely fill the existing with new water?' Van Aarde (1994:346) noem dit 'n hermeneutiese dilemina. Hy gebruik begrippe soos 'kultuurimperialisme' en 'Eurosentrisme' om die kerk se tradisionele benadering van die problematiek te beskryf (Van Aarde 1994:349). Die antwoord lê in 'n balans wat gevind moet word tussen die suiwer verkondiging van die evangelie en die respek $v i r$ tradisionele kultuur, denkwyses en geloof van die mense aan wie die evangelie verkondig word.

\section{Literatuurverwysings}

Bavinck, J H 1954. Inleiding in de Zendingswetenschap. Kampen: Kok. Bosch, J D 1979. Heil vir die wêreld. Pretoria: N G Kerkboekhandel. 
Neill, S 1977. Christian faith and other faiths. London: Oxford University Press. Oosthuizen, G C 1977. Godsdienste van die wêreld. Pretoria: N G Kerkboekhandel. Van Aarde, A G 1994. Kultuurimperialisme as hemeneutiese dilemma: EersteWêreldse en Derde-Wêreldse perspektiewe op Jesus as Seun van God. HTS Jg 50/1 \& 2, 345-367.

Van der Westhuizen, H G 1990. Kerk en kerstening. Pretoria: Kital.

Verkuyl, J 1978. Contemporary missiology. Grand Rapids: Eerdmans. 